\title{
Biochar in substrate composition for production of teak seedlings
}

\author{
Fabiana Abreu Rezende(1), Victor Alexandre Hardt Ferreira dos Santos ${ }^{(2)}$, \\ Claudia Maria Branco de Freitas Maia ${ }^{(3)}$ and Marina Moura Morales ${ }^{(1)}$
}

\begin{abstract}
(1)Embrapa Agrossilvipastoril, Rodovia dos Pioneiros, MT-222, Km 2,5, Zona Rural, Caixa Postal 343, CEP 78550-970 Sinop, MT, Brazil. E-mail: fabiana.rezende@embrapa.br, marina.morales@embrapa.br (2)Instituto Nacional de Pesquisas da Amazônia, Avenida André Araújo, Caixa Postal 478, CEP 69060-001 Manaus, AM, Brazil. E-mail: victor.santos@inpa.gov.br ${ }^{(3)}$ Embrapa Florestas, Estrada da Ribeira, Km 111, Guaraituba, Caixa Postal 319, CEP 83411-000 Colombo, PR, Brazil. E-mail: claudia.maia@embrapa.br
\end{abstract}

\begin{abstract}
The objective of this work was to evaluate the development and quality of clonal seedlings of teak (Tectona grandis) grown in substrate with two types of biochar. The assay was carried out in a randomized complete block design, with ten treatments and four replicates: CS, commercial substrate, composed of pine bark and vermiculite at a ratio of 4:1; NS, nursery substrate composed of carbonized rice husk and coconut fiber at 1:1; and the remaining treatments were composed of the inclusions of biochar (BC) or activated biochar (BCA) in the CS, at the proportions of $25,50,75$, and $100 \%$. The development and quality parameters of seedlings were evaluated 90 days after striking the minicuttings in the substrates. BCA substrate additions at 25,50 , and $100 \%$ allowed for a development of height and stem diameter comparable to that of the NS. Biochar without the activation procedure does not improve quality parameters of seedlings, in comparison with the commercial substrate. The use of $25 \%$ activated biochar added to the commercial substrate is enough to improve seedling growth performance to the same level as that provided by the already validated NS.
\end{abstract}

Index terms: Tectona grandis, agroindustrial waste, biochar activity, pyrolysis, seedling quality.

\section{Biochar na composição de substratos para a produção de mudas de teca}

Resumo - O objetivo deste trabalho foi avaliar o desenvolvimento e a qualidade de mudas clonais de teca (Tectona grandis) cultivadas em substrato com dois tipos de biochar. O ensaio foi realizado em delineamento de blocos ao acaso, com dez tratamentos e quatro repetições: SC, substrato comercial, composto de casca de pinus e vermiculita à proporção de 4:1; SV, substrato do viveiro, composto de casca de arroz carbonizada e fibra de coco a 1:1; e o restante dos tratamentos foi composto de inclusões de biochar (B) e biochar ativado (BA), nas proporções de 25, 50, 75 e 100\% do SC. Os parâmetros de desenvolvimento e qualidade das mudas foram avaliados 90 dias após o plantio das estacas nos substratos. A adição de 25, 50 e 100\% de BA possibilitou o desenvolvimento em altura e diâmetro do coleto comparável ao proporcionado pelo SV. O biochar sem o procedimento de ativação não melhora os parâmetros de qualidade das mudas, em comparação ao substrato comercial. A adição de biochar ativado na proporção de $25 \%$ já é suficiente para melhorar o crescimento das mudas para o mesmo nível proporcionado pelo já validado SV.

Termos para indexação: Tectona grandis, resíduo agroindustrial, atividade do biochar, pirólise, qualidade de mudas.

\section{Introduction}

The timber industry generates a significant amount of wood residues in its production process, $50 \%$ of the amount of wood, on average (Koopmans \& Koppejan, 1998). Proper destination to these residues should be considered, and their use as reconstituted wood, briquettes, pellets, fertilizer, and biochar is common (Kwapinski et al., 2010; Woolf et al., 2010). These alternative uses can transform valueless residues in an important by-product of the industrial process and incorporate additional income to the sector. Biochar production has a great potential, mainly as a soil conditioner (Van Zwieten et al., 2010; Petter \& Madari, 2012), or as a component of seedling substrates (Lehmann \& Rondon, 2006; Ogawa \& Okimori, 2010; Dharmakeerthi et al., 2012; Petter et al., 2012).

Biochar is treated here as the pyrolyzed biomass, prepared specifically for soil application to increase soil fertility and to alleviate anthropic greenhouse gas emissions, by $\mathrm{CO}_{2}$ sequestration, or $\mathrm{N}_{2} \mathrm{O}$ emission decrease (Novotny et al., 2015). Biochar is a porous, carbonaceous, pyrogenic C-rich material, whose 
structure can vary according to the thermal treatment used in its production. Although it is a very chemically stable material, pyrogenic $\mathrm{C}$ can show a relatively high activity. Biochar reactivity can originate from the presence of charged sites, as the ones resulting from hydroxyl or carboxyl ionization. This type of biochar can be produced by using lower temperatures (around $450^{\circ} \mathrm{C}$ degrees) and short residence time (Novotny et al., 2015). Biochar activity can also be derived from its physical adsorption capacity, which results from its high porosity and specific surface area (SSA).

A biochar with high SSA and porosity can be produced at high temperatures $\left(700^{\circ} \mathrm{C}\right.$ degrees for instance), when most of condensed volatiles is removed from the carbonaceous matrix allowing porous cleaning. This process is exactly the same as that used to produce activated charcoal, a powerful adsorbent. The activation treatment can promote the release of volatiles, formation of crystalline $\mathrm{C}$, improvement of organic radical charges in the carbon surface, and increased surface area and porosity (Downie et al., 2009).

A material that acts as a slow release matrix for nutrients, such as active biochar, can be of great importance for the production of seedlings. A substrate for seedlings should have low density and good water retention capacity (Altland \& Krause, 2012); biochar, when present in substrate compositions, increases water retention both at low and high matric potentials, and improves the conditions for the development of seedlings (Souza et al., 2006; Lazcano et al., 2009). Specifically for the minicutting propagation technique, the substrate used for rooting of seedlings has to provide adequate aeration, moisture, and the necessary nutrition for root development (Kratz et al., 2012). However, appropriate substrate for rooting depends on the species (of biochar and seedlings), type of stake, propagation system, cost, and availability of components. The most used substrates for rooting are vermiculite, compost, sand, carbonized rice husk (that could be considered as biochar, by definition), sawdust, and soil (Hartmann et al., 2002).

Recently, teak (Tectona grandis L.f) has been attracting a lot of atention in Brazil, due to its high wood quality for producing fine furniture, and to its high use potential in the naval industry. Considering the state of Mato Grosso alone, in Brazil, the planted area with teak is around 60 thousand hectares (Anuário..., 2013), and little is known about the use of biochar as substrate for the production of teak seedlings.
The objective of this work was to investigate the development and quality of clonal seedlings of teak, cultivated in substrates with biochar and activated biochar.

\section{Materials and Methods}

The work was carried out at Flora Sinop nursery, between December 2012 and March 2013, in Sinop,

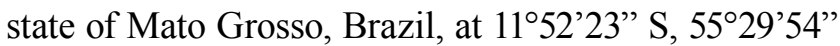
$\mathrm{W}$, and at $384 \mathrm{~m}$ altitude. The annual averages of temperature and rainsfalls are $24^{\circ} \mathrm{C}$ and $1,900 \mathrm{~mm}$, respectively, and the relative humidity ranges between 80 and 35\% during the year (Souza et al., 2012). Teak minicuttings commercially known as Proteca A1 were used. The propagules were collected in a clonal minigarden.

We used a randomized complete block design, with ten treaments, four replicates, and 50 seedlings per plot. The treatments consisted of the following substrates: CS, composed by pine bark and vermiculite $(4: 1 \mathrm{~m} / \mathrm{m})$; NS, composed by carbonized rice husk and coconut fiber $(1: 1 \mathrm{~m} / \mathrm{m})$; and binary mixtures of $\mathrm{CS}$ with biochar (BC), or activated biochar (BCA) at 25, 50, 75, and 100\% - BC25, BC50, BC75, BC100, BCA25, BCA50, BCA75 and BCA100, respectively.

Biochar was produced from fresh sawdust of tropical native species, obtained in sawmills in Sinop. To obtain the $\mathrm{BC}$, sawdust was processed in a slow pyrolysis reactor (vertical furnace), with $25 \mathrm{~min}$ residence time, at $450^{\circ} \mathrm{C}$. The $\mathrm{BCA}$ was prepared in a pyrolysis reactor (horizontal tubular oven) at $650^{\circ} \mathrm{C}$, with water steam injection during the process. Phenol proportions $(-\mathrm{OH})$ decreased after biochar activation (Figure 1), and the relative amount of carboxyl $(-\mathrm{COOH})$ and lactone $(-\mathrm{OCOH})$ groups increased, showing some degree of funcionalization. Carboxyl groups, being a stronger acid group than hydroxyl, can dissociate as carboxylate, creating ionic charges and increasing the cationic exchange capacity of biochar. Linhares et al. (2012) say that biochar interaction with the environment can form new compounds with carboxyl groups directly connected to the charcoal recalcitrant aromatic structures, contributing to the cation exchange capacity. These processes were conducted according to Fidel (2012) and Tsechansky \& Graber (2014). The chemical characterization of the biochars 
$-\mathrm{pH}, \mathrm{Ca}^{+2}, \mathrm{Mg}^{+2}, \mathrm{~K}^{+}$, and $\mathrm{P}$ contents (Claessen, 1997) are shown in Figure 2.

The substrates were homogeneized with an electric mixer, and chemical slow release fertilizers were equally added to all treatments: 225 g Basacote $6 \mathrm{M}$, $225 \mathrm{~g}$ Basacote 3M, and $600 \mathrm{~g}$ FH Eucalipto Heringer in $150 \mathrm{~L}$ of substrate. The composition of Basacote $6 \mathrm{M}$ and Basacote $3 \mathrm{M}$ are 16-08-12 NPK, with: $2 \% \mathrm{Mg}$, $5 \% \mathrm{~S}, 0.4 \% \mathrm{Fe}, 0.02 \% \mathrm{~B}, 0.02 \% \mathrm{Zn}, 0.05 \% \mathrm{Cu}$, and $0.06 \% \mathrm{Mn}$. The composition of FH Eucalipto Heringer is 4-31-4 NPK, with: $0.4 \% \mathrm{Zn}$ and $22 \% \mathrm{Co}$.

Plastic tubes used for rooting were $12 \mathrm{~cm}$ long, with $50 \mathrm{~cm}^{3}$ capacity and 4 to 6 longitudinal grooves. They were previously sterilized in water at $80^{\circ} \mathrm{C}$, for $30 \mathrm{~s}$ (Kohmann \& Borja, 2002).

Greenhouse environmental conditions were monitored to keep the temperature around $30^{\circ} \mathrm{C}$, and the relative humidity above $80 \%$. After 20 days of staking, teak seedlings were relocated in a shade house, with $50 \%$ attenuation of solar radiation, and, after 30 days more, the seedlings were taken to full sun. In early production stages, seedling density per tray was one per cell and, in the full sun environment, the density was one plant every four cells.

The substrates were physically characterized for the following parameters: apparent and real density; total porosity; water retention at field capacity; and particle size fractionation(Table 1). The water retention capacity in saturated mass was calculated after weighing the substrates at equilibrium drainage and atmospheric pressure, and by subtracting from it the dry substrate weight. Substrate physical characterization procedures were carried out in the soil analysis laboratory of the Universidade Federal do Mato Grosso.

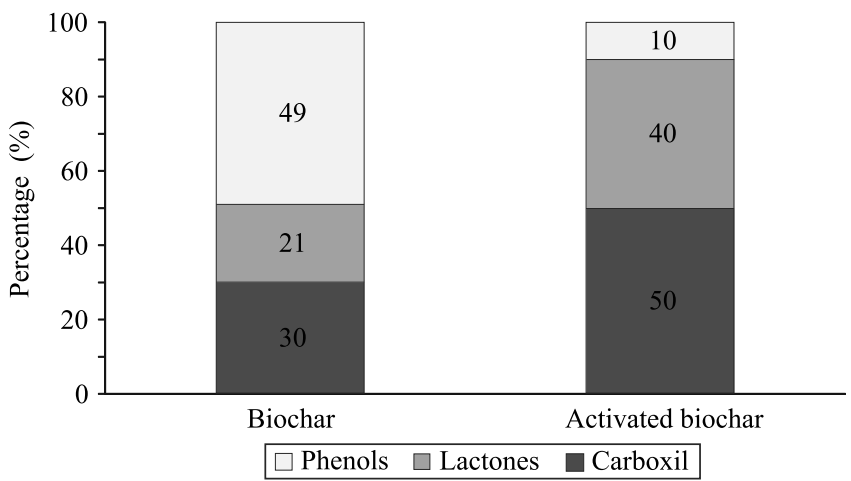

Figure 1. Surface functional groups in biochar $(\mathrm{BC})$ and activated biochar (BCA).
Stem diameter and seedling height were measured 90 days after planting. Thereafter, seedlings were removed from the nursery and sent to the biomass laboratory at Embrapa Agrossilvopastoril, in order to obtain their fresh and dry weight. Fresh and dry weight of roots and shoots were also obtained. Dry weight was obtained
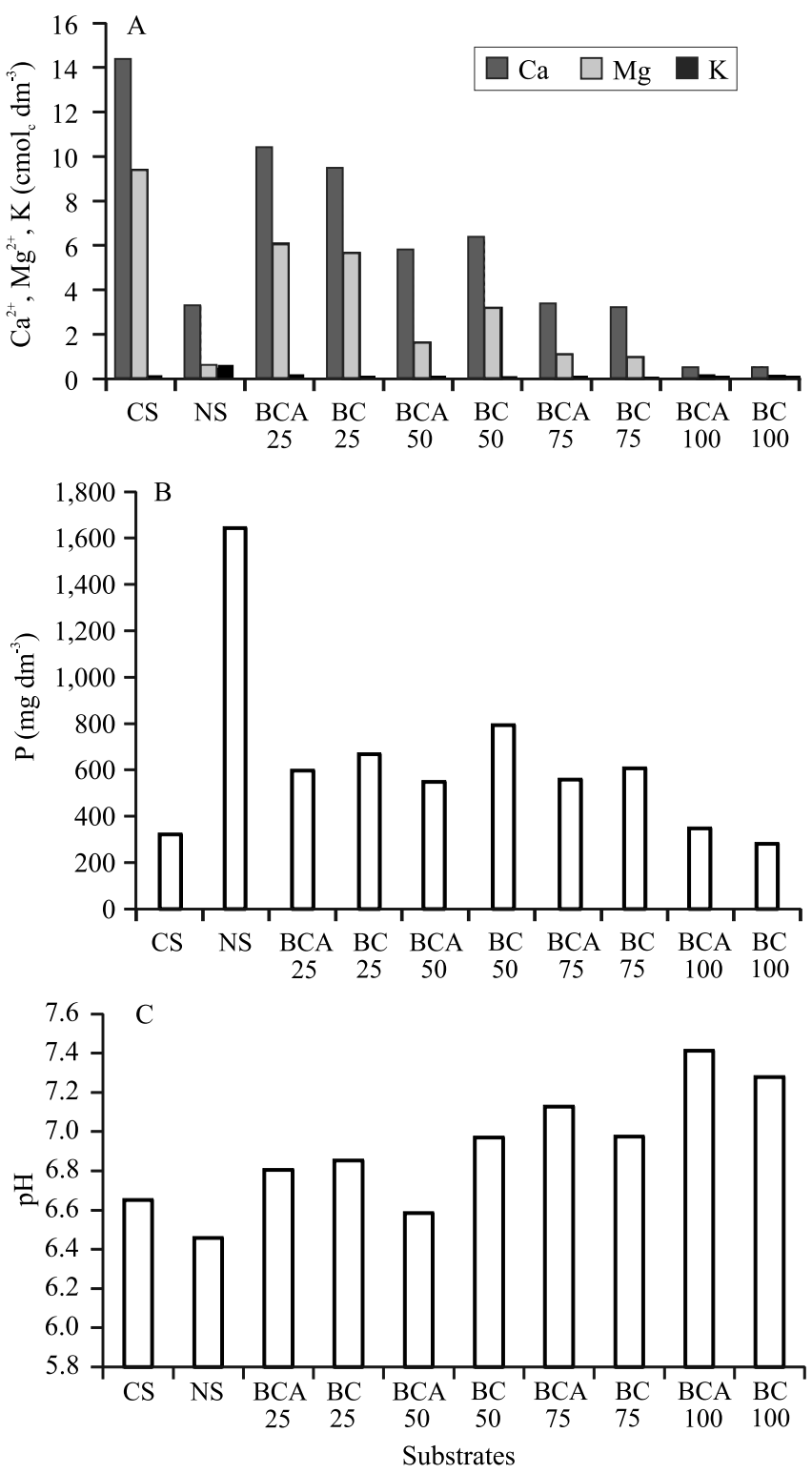

Figure 2. Contents of $\mathrm{Ca}^{2+}, \mathrm{Mg}^{2+}$, and $\mathrm{K}^{+}(\mathrm{A})$, besides $\mathrm{P}$ (B) and $\mathrm{pH}$ values (C) in the evaluated substrates: $\mathrm{CS}$, commercial substrate, $100 \%$; NS, substrate used in nurseries, $100 \%$; $\mathrm{BC}$, biochar; and $\mathrm{BCA}$, activated biochar. The numbers following the initials indicate the biochar rates used in the mixture with CS.

Pesq. agropec. bras., Brasília, v.51, n.9, p.1449-1456, set. 2016 DOI: 10.1590/S0100-204X2016000900043 
after drying the material at $60^{\circ} \mathrm{C}$ for 72 hours. Only the 20 seedlings located at the center of the plots (50 seedlings) were used as the available plot. The quality index of Dickson (QID) was calculated according to the equation (Dickson et al., 1960) QID $=$ TFM/(H/D + $\mathrm{SDM} / \mathrm{RDM}$ ), in which: TFM is the total fresh biomass (g); SDW, shoot dry weight (g); RDM, root dry weight (g); H, height (cm); and D, stem diameter (mm). Fonseca et al. (2002) say that QID is a good indicator of seedling quality because it considers the robustness and the distribution equilibrium of biomass in the plants, using several important parameters to its determination.

The statistical analysis was done considering a twoway multivariate analysis of variance, and a subsequent analysis of variance with Bonferroni correction. Means were compared using the Scott-Knott test, at 5\% probability, and regression analyses were used when necessary. All statistical analyses were performed with the R software (R Core Team, 2012).

\section{Results and Discussion}

Seedling responses to biochar were consistently positive and strong. BCA applications and NS, in general, significantly increased stem diameter, seedling height, RDM, TFM, SDM, and QID of seedlings, in comparison with $\mathrm{BC}$ and $\mathrm{CS}$ substrates (Figure 3). These results agree with the literature, which, in general, shows strong positive growth responses of seedlings to the use of biochar in the nursery phase (Cernansky, 2015; DeLuca et al., 2015; Ghosh et al., 2015; Thomas \& Gale, 2015).

The highest stem diameter was observed for BCA100, followed by BCA25, BCA50, BCA75, and NS treatments (Figure 3), while the smallest one was observed in the treatments with $\mathrm{BC}$ additions to $\mathrm{CS}$ $(\mathrm{BC} 25, \mathrm{BC} 50, \mathrm{BC} 75$, and $\mathrm{BC} 100)$ and in the control treatment CS. Seedling height showed a similar

Table 1. Apparent (Da) and real (Dr) density, and total porosity in the evaluated substrates: CS, commercial substrate; NS, substrate used in nurseries; BC, biochar; and BCA, activated biochar.

\begin{tabular}{lccc}
\hline Substrate & Dr & Da & $\begin{array}{c}\text { Porosity } \\
(\%)\end{array}$ \\
\hline CS & -1.16 & 0.47 & 59 \\
NS & 1.02 & 0.15 & 85 \\
Activated biochar & 1.67 & 0.24 & 85 \\
Biochar & 1.27 & 0.31 & 75 \\
\hline
\end{tabular}

response pattern, with best results for treatments with BCA additions and for NS substrate. The highest values for root and shoot dry weight, total freshweight, and QDI were also obtained with BCA additions and with NS substrate.

Seedling height and stem diameter did not show a linear behavior with BCA doses, displaying a curve inflection at BCA75, probably due to the largest number of small particles $(<0.125 \mathrm{~mm})$ in BCA (Figure 4), which could have decreased substrate macroporosity as a result of its increasing additions. However, future tests are important to verify the causes of this result. Stem diameter and seedling height are widely used in the investigation of seedling development in nurseries, and biochar effects on these parameters can be beneficial (Kwapinski et al., 2010; Dharmakeerthi et al., 2012) or absent, depending on the evaluated species (Zanetti et al., 2003; Petter \& Madari, 2012).

As to seedling quality, QID increased substantialy with BCA additions, peaking at the dose of $65 \%$ (Figure 5). The improved water retention in NS and BCA substrates (Figure 6) could be the responsible for the positive results of their use in the development parameters and quality (QID) of seedling. The positive effects of BCA as substrate conditioner on stem diameter and plant height, reported in the literature (Souza et al., 2006; Ogawa \& Okimori, 2010; Petter et al., 2012), are strongly related to its water holding capacity, since $\mathrm{CO}_{2}$ assimilation process is regulated by water availability, and it has great influence on seedling development for height and stem diameter (Kozlowski, 1962; Altland \& Krause, 2012). Altland \& Krause (2012) mention that root system is highly sensitive to physical and chemical conditions of the substrate. Therefore, the low dry weight of roots and shoots using substrates with BC and CS, in the present work, are possibly related to their low water retention capacity (Ishii \& Kadoya, 1994; Yang et al., 2015). Nonetheless, charcoal application has been shown to increase soil water retention capacity (Beck et al., 2011), and such improvement in soil physical and chemical properties can be effective in enhancing plant growth (Lehmann et al., 2003; Steiner et al., 2007; Graber et al., 2010; Cernansky, 2015).

The ideal porosity for substrates is between 70 and $80 \%$ (Gonçalves et al., 2000). Both NS and BCA showed $85 \%$ porosity, while BC showed $75 \%$, and CS, $59 \%$ (Table 1). NS and BCA also had lower values of

Pesq. agropec. bras., Brasília, v.51, n.9, p.1449-1456, set. 2016

DOI: 10.1590/S0100-204X2016000900043 

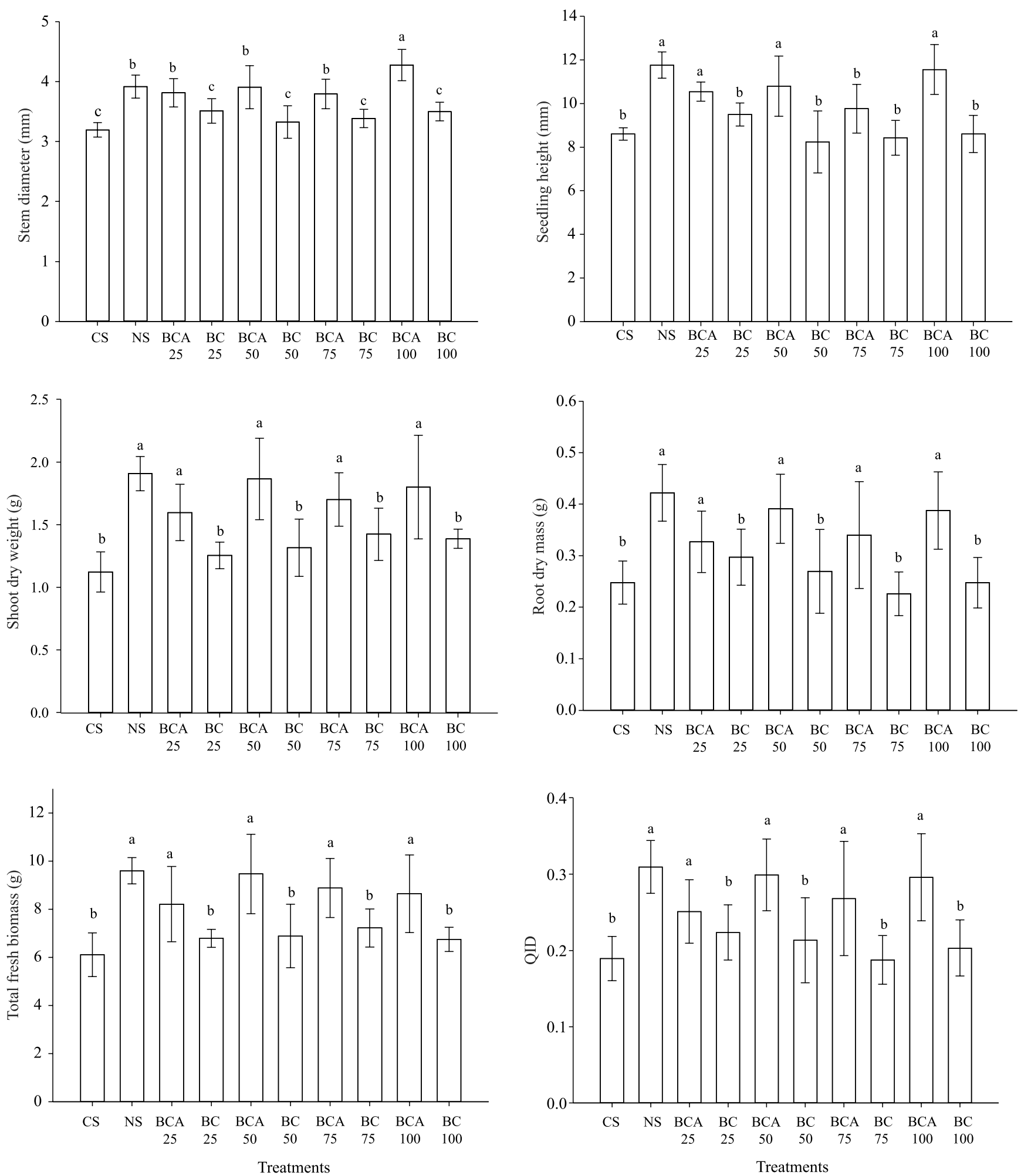

Figure 3. Stem diameter, height, shoot and root dry weight, total fresh biomass, and quality index of Dickson (QID) for Tectona grandis seedlings in different substrates: CS, 100\% commercial substrate; NS, $100 \%$ substrate used in nurseries; $\mathrm{BC}$, biochar; and BCA, activated biochar. The numbers following the initials indicate the biochar rates used in the mixture with CS. Means followed by equal letters do not differ by Scott-Knott test, at $5 \%$ probability. Error bars represent the standard deviations. 
apparent density than BC and CS. The ideal substrate density for plant propagation in trays is between 0.1 and $0.3 \mathrm{~g} \mathrm{~cm}^{-3}$, for recipients with $15 \mathrm{~cm}$ height, and between 0.3 to $0.5 \mathrm{~g} \mathrm{~cm}^{1}$, for recipients with $20-30 \mathrm{~cm}$ height (Kämpf, 2005).

The quality index of Dickson, expressed by QID (Dickson et al., 1960), is considered a good measure

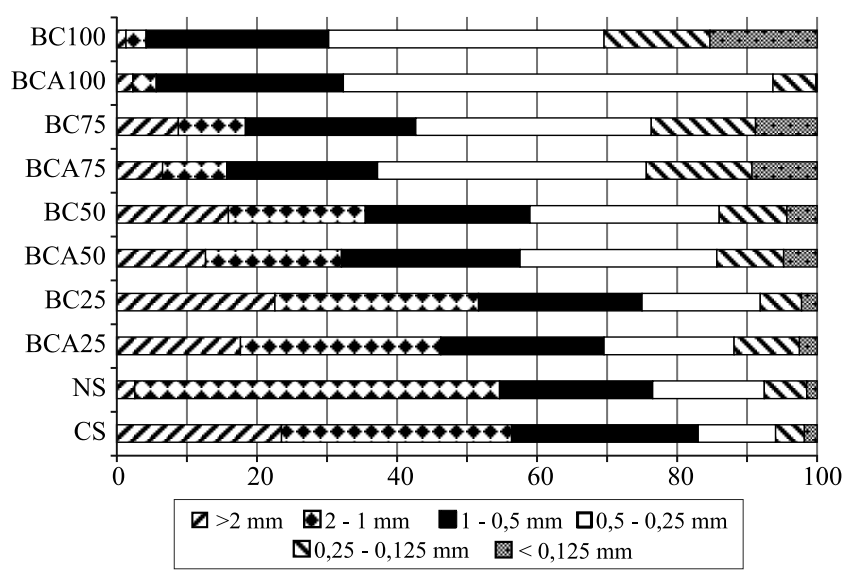

Figura 4. Particle size in the evaluated substrates: CS, $100 \%$ commercial substrate; NS, $100 \%$ substrate used in nurseries; $\mathrm{BC}$, biochar; and $\mathrm{BCA}$, activated biochar. The numbers following the initials indicate the biochar rates used in the mixture with CS.

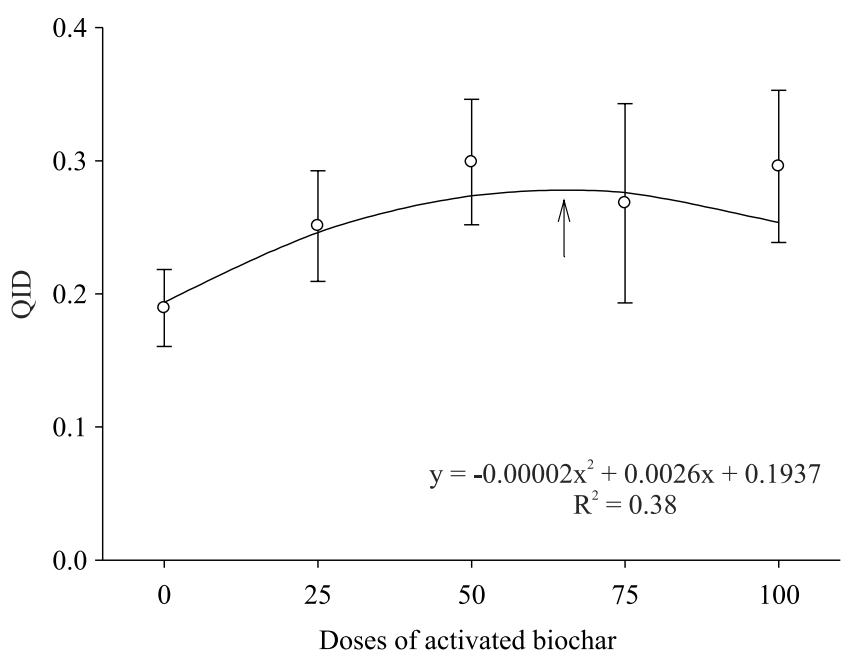

Figure 5. Quality index of Dickson (QID) for Tectona grandis affected by activated biochar (BCA) proportions used in the mixture with commercial substrate. The measures were made 90 days after striking the minicuttings in the substrate. Error bars represent the standard deviations.

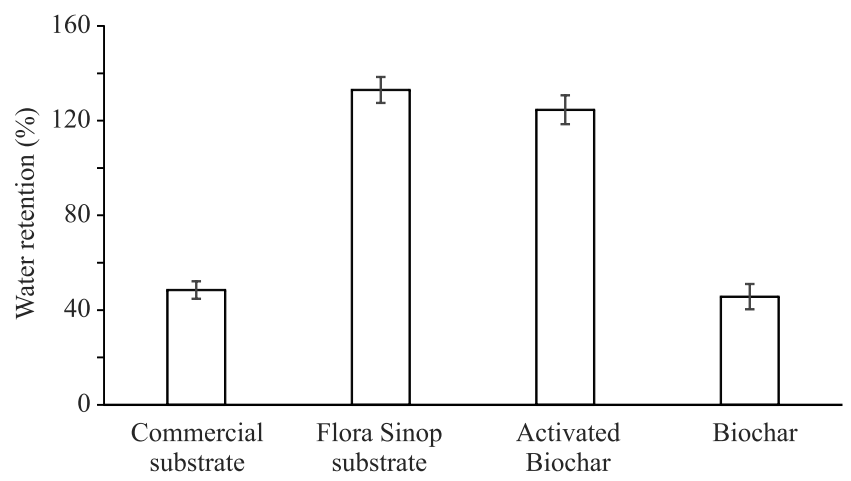

Figure 6. Water retention capacity of the evaluated substrates: CS, commercial substrate; NS, substrate used in nurseries; BC, biochar; and BCA, activated biochar. Error bars represent the standard deviations.

for evaluating the seedling quality of forest species in general (Davis \& Jacobs, 2005; Bayala et al., 2009), including teak (Tiwari et al., 2002; Yasodha et al., 2004; Zhou et al., 2012). Moreover, biochar was reported as a suitable substrate conditioner for the production of Eucalyptus citriodora seedlings (Petter et al., 2012), when used in proportions from 7.5 to $15 \%$. However, the authors found that the same doses did not influence on quality of Eucalyptus urophylla seedlings.

In future studies, other parameters can be evaluated, in order to detect biochar effects on seedling production of forest species. There are favorable reports of its effects on rooting of Paullinia cupana (Arruda et al., 2007), and on leaf senescence in Tachigali vulgaris (Souchie et al., 2011). Rivière \& Caron (2001) stated that the search for alternative substrates for nursery plants is very important, especially if they are environmentally friendly. The research should focus on biochar physical properties, mainly as to the management of stored water and of air fluxes in the substrate, but it also should assess nutrient availability, and adequate air and water requirements for growth.

\section{Conclusions}

1. Activated biochar added to commercial substrate increases the development of Tectona grandis seedlings both for height and stem diameter, and provides growth performance comparable to that of nursery substrate.

2. Biochar without the activation procedure does not improve quality parameters of seedlings, in comparison with the commercial substrate. 
3. The use of $25 \%$ activated biochar added to commercial substrate is enough to improve growth performance to the same level as that provided by the already validated nursery substrate.

\section{Acknowledgments}

To Fundação de Amparo à Pesquisa do Estado de Mato Grosso (Fapemat), to Conselho Nacional de Desenvolvimento Científico e Tecnológico (CNPq, process No. 482999/2011), and to Empresa Brasileira de Pesquisa Agropecuária (Embrapa, project No. 02120210000), for financial support.

\section{References}

ALTLAND, J.E.; KRAUSE, C.R. Substituting pine wood for pine bark affects physical properties of nursery substrates. HortScience, v.47, p.1499-1503, 2012.

ANUÁRIO Estatístico ABRAF 2013: ano base 2012. Brasília: ABRAF, 2013. 146p.

ARRUDA, M.R. de; PEREIRA, J.C.R.; MOREIRA, A.; TEIXEIRA, W.G. Enraizamento de estacas herbáceas de guaranazeiro em diferentes substratos. Ciência e Agrotecnologia, v.31, p.236-241, 2007. DOI: $10.1590 / \mathrm{S} 1413-70542007000100035$.

BAYALA, J.; DIANDA, M.; WILSON, J.; OUÉDRAOGO, S.J.; SANON, K. Predicting field performance of five irrigated tree species using seedling quality assessment in Burkina Faso, West Africa. New Forests, v.38, p.309-322, 2009. DOI: 10.1007/s11056-009-9149-4.

BECK, D.A.; JOHNSON, G.R.; SPOLEK, G.A. Amending greenroof soil with biochar to affect runoff water quantity and quality. Environmental Pollution, v.159, p.2111-2118, 2011. DOI: 10.1016/j. envpol.2011.01.022.

CERNANSKY, R. State-of-the-art soil. Nature, v.517, p.258-260, 2015. DOI: $10.1038 / 517258$ a.

CLAESSEN, M.E.C. (Org.). Manual de métodos de análise de solos. 2.ed. rev. e atual. Rio de Janeiro: Embrapa-CNPS, 1997. 212p. (Embrapa-CNPS. Documentos, 1).

DAVIS, A.S.; JACOBS, D.F. Quantifying root system quality of nursery seedlings and relationship to outplanting performance. New Forests, v.30, p.295-311, 2005. DOI: 10.1007/s11056-005-7480-y.

DELUCA, T.H.; GUNDALE, M.J.; MACKENZIE, M.D.; JONES, D.L. Biochar effects on soil nutrient transformations. In: LEHMANN, J.; Joseph, S. (Ed.). Biochar for environmental management: science, technology and implementation. $2^{\text {nd }}$ ed. Londres: Earthscan, 2015. p.421-454.

DHARMAKEERTHI, R.S.; CHANDRASIRI, J.A.S.; EDIRIMANNE, V.U. Effect of rubber wood biochar on nutrition and growth of nursery plants of Hevea brasiliensis established in an Ultisol. SpringerPlus, v.1, p.84, 2012. DOI: 10.1186/2193-1801-1-84.
DICKSON, A.; LEAF, A.L.; HOSNER, J.F. Quality appraisal of white spruce and white pine seedling stock in nurseries. Forestry Chronicle, v.36, p.10-13, 1960. DOI: 10.5558/tfc36010-1.

DOWNIE, A.; CROSKY, A.; MUNROE, P. Physical properties of biochar. In: Lehmann, J.; Joseph, S. (Ed.). Biochar for environmental management: science and technology. Londres: Earthscan, 2009. p.13-29.

FIDEL, R.B. Evaluation and implementation of methods for quantifying organic and inorganic components of biochar alkalinity. 2012. 86p. Dissertation (Master) - Iowa State University, Ames. Available at: <http://lib.dr.iastate.edu/cgi/viewcontent. cgi? article $=3759 \&$ context $=$ etd $>$. Accessed on: Oct. 102015 .

FONSECA, E. de P.; VALERI, S.V.; MIGLIORANZA, E.; FONSECA, N.A.N.; COUTO, L. Padrão de qualidade de mudas de Trema micrantha (L.) Blume, produzidas sob diferentes períodos de sombreamento. Revista Árvore, v.26, p.515-523, 2002. DOI: 10.1590/ S0100-67622002000400015.

GHOSH, S.; OW, L.F.; WILSON, B. Influence of biochar and compost on soil properties and tree growth in a tropical urban environment. International Journal of Environmental Science and Technology, v.12, p.1303-1310, 2015. DOI: 10.1007/s13762-014-0508-0.

GONÇALVES, J.L. de M.; SANTARELLI, E.G.; MORAES NETO, S.P.; MANARA, M.P. Produção de mudas de espécies nativas: substrato, nutrição, sombreamento e fertilização. In: GONÇALVES, J.L. de M.; BENEDETTI, V. (Ed.). Nutrição e fertilização florestal. Piracicaba: IPEF, 2000. cap.11, p.309-350.

GRABER, E.R.; HAREL, Y.M.; KOLTON, M.; CYTRYN, E.; SILBER, A.; DAVID, D.R.; TSECHANSKY, L.; BORENSHTEIN, M.; ELAD, Y. Biochar impact on development and productivity of pepper and tomato grown in fertigated soilless media. Plant and Soil, v.337, p.481-496, 2010. DOI: 10.1007/s11104-010-0544-6.

HARTMANN, H.T.; KESTER, D.E.; DAVIES JUNIOR,F.T.; GENEVE, R.L. Plant Propagation: principles and pratices. $7^{\text {th }}$ ed. New Jersey: Prentice Hall, 2002. 880p.

ISHII, T.; KADOYA, K. Effects of charcoal as a soil conditioner on citrus growth and vesicular-arbuscular mycorrhizal development. Journal of the Japanese Society for Horticultural Science, v.63, p.529-535, 1994. DOI: 10.2503/jjshs.63.529.

KÄMPF, A.N. Substrato. In: KÄMPF, A.N. Produção comercial de plantas ornamentais. 2.ed. Guaíba: Agrolivros: Rígel, 2005. p.45-72.

KOZLOWSKI, T.T. Tree growth. New York: Ronald Press, 1962. $149 \mathrm{p}$.

KOHMANN, K.; BORJA, I. Hot-water treatment for sanitizing forest nursery containers: effects on container microflora and seedling growth. Scandinavian Journal of Forest Research, v.17, p.111-117, 2002. DOI: $10.1080 / 028275802753626755$.

KOOPMANS, A.; KOPPEJAN, J. Generation, utilization and availability of agricultural and forest residues. In: REGIONAL EXPERT CONSULTATION ON MODERN APPLICATIONS OF BIOMASS ENERGY, 1997, Kuala Lumpur, Malaysia. Proceedings. Bangkok: FAO, 1998. (FAO. RWEDP Report $n^{\circ} 36$ ). Available at: $\quad<$ http://www.ces.iisc.ernet.in/energy/HC270799/RWEDP/ acrobat/p_residues.pdf $>$. Accessed on: Sept. 122015. 
KRATZ, D.; WENDLING, I.; PIRES, P.P. Miniestaquia de Eucalyptus benthamii x E. dunnii em substratos à base de casca de arroz carbonizada. Scientia Forestalis, v.40, p.547-556, 2012.

KWAPINSKI, W.; BYRNE, C.M.P.; KRYACHKO, E.; WOLFRAM, P.; ADLEY, C.; LEAHY, J.J.; NOVOTNY, E.H.; HAYES, M.H.B. Biochar from biomass and waste. Waste and Biomass Valorization, v.1, p.177-189, 2010. DOI: 10.1007/s12649-010-9024-8.

LAZCANO, C.; ARNOLD, J.; TATO, A.; ZALLER, J.G.; DOMÍNGUEZ, J. Compost and vermicompost as nursery pot components: effects on tomato plant growth and morphology. Spanish Journal of Agricultural Research, v.7, p.944-951, 2009. DOI: $10.5424 /$ sjar/2009074-1107.

LEHMANN, J.; RONDON, M. Bio-char soil management on highly weathered soils in the humid tropics. In: UPHOFF, N.; BALL, A.S.; FERNANDES, E.; HERREN, H.; HUSSON, O.; LAING, M.; PALM, C.; PRETTY, J.; SANCHEZ, P.; SANGINGA, N.; THIES, J. (Ed.). Biological approches to sustainable soil systems. Boca Raton: CRC Press, 2006. p.517-530. DOI: 10.1201/9781420017113. ch36.

LEHMANN, J.; SILVA JÚNIOR, J.P. da; STEINER, C.; NEHLS, T.; ZECH, W.; GLASER, B. Nutrient availability and leaching in an archaeological Anthrosol and a Ferralsol of the Central Amazon basin: fertilizer, manure and charcoal amendments. Plant and Soil, v.249, p.343-357, 2003. DOI: 10.1023/A:1022833116184.

LINHARES, C.R.; LEMKE, J.; AUCCAISE, R.; DUÓ, D.A.; ZIOLLI, R.L.; KWAPINSKI, W.; NOVOTNY, E.H. Reproducing the organic matter model of anthropogenic dark earth of Amazonia and testing the ecotoxicity of functionalized charcoal compounds. Pesquisa Agropecuária Brasileira, v.47, p.693-698, 2012. DOI: 10.1590/S0100-204X2012000500009.

NOVOTNY, E.H.; MAIA, C.M.B. de F.; CARVALHO, M.T. de M.; MADARI, B.E. Biochar: Pyrogenic carbon for agricultural - a critical review. Revista Brasileira de Ciência do Solo, v.39, p.321-344, 2015. OGAWA, M.; OKIMORI, Y. Pioneering works in biochar research, Japan. Australian Journal of Soil Research, v.48, p.489-500, 2010. DOI: $10.1071 /$ SR10006.

PETTER, F.A.; ANDRADE, F.R.; MARIMON JÚNIOR, B.H.; GONÇALVEZ, L.G.; SCHOSSLER, T.R. Biochar como condicionador de substrato para a produção de mudas de eucalipto. Revista Caatinga, v.25, p.44-51, 2012.

PETTER, F.A.; MADARI, B.E. Biochar: agronomic and environmental potential in Brazilian savannah soils. Revista Brasileira de Engenharia Agrícola e Ambiental, v.16, p.761-768, 2012. DOI: $10.1590 /$ S1415-43662012000700009.

R CORE TEAM. R: a language and environment for statistical computing. Vienna: R Foundation for Statistical Computing, 2012. Available at: <http://www.R-project.org/>. Accessed on: Aug. 162015.

RIVIÈRE, L.M.; CARON, J. Research on substrates: state of the art and need for the coming 10 years. Acta Horticulturae, v.548, p.2941, 2001. DOI: 10.17660/ActaHortic.2001.548.1.

SOUCHIE, F.F.; MARIMON JUNIOR, B.H.M.; PETTER, F.A.; MADARI, B.E.; MARIMON, B.S.; LENZA, E. Carvão pirogênico como condicionante para substrato de mudas de Tachigali vulgaris L.G. Silva \& H.C. Lima. Ciência Florestal, v.21, p.811-821, 2011. DOI: $10.5902 / 198050984526$.

SOUZA, A.P.; CASAVECCHIA, B.H.; STANGERLIN, D.M. Avaliação dos riscos de ocorrência de incêndios florestais nas regiões Norte e Noroeste da Amazônia Matogrossense. Scientia Plena, v.8, p.1-14, 2012.

SOUZA, G.K.A.; TEIXEIRA, W.G.; REIS R.A.; CHAVES, F.C.M.; XAVIER, J.J.B.N. Growth of crajiru (Arrabidaea chica Verlot.) in different growing media. Revista Brasileira de Plantas Medicinais, v.8, p.61-65, 2006.

STEINER, C.; TEIXEIRA, W.G.; LEHMANN, J; NEHLS, T; MACEDO, J.L.V. de; BLUM W.E.H.; ZECH, W. Long term effects of manure, charcoal and mineral fertilization on crop production and fertility on a highly weathered Central Amazonian upland soil. Plant and Soil, v.291, p.275-290, 2007. DOI: 10.1007/s11104-007-9193-9.

THOMAS, S.C.; GALE, N. Biochar and forest restoration: a review and meta-analysis of tree growth responses. New Forests, v.46, p.931946, 2015. DOI: 10.1007/s11056-015-9491-7.

TIWARI, S.K.; TIWARI, K.P.; SIRIL, E.A. An improved micropropagation protocol for teak. Plant Cell, Tissue and Organ Culture, v.71, p.1-6, 2002. DOI: 10.1023/A:1016570000846.

TSECHANSKY, L.; GRABER, E.R. Methodological limitations to determining acidic groups at biochar surfaces via the Boehm titration. Carbon, v.66, p.730-733, 2014. DOI: 10.1016/j.carbon.2013.09.044.

VAN ZWIETEN, L.; KIMBER, S.; MORRIS, S.; CHAN, K.Y.; DOWNIE, A.; RUST, J.; JOSEPH, S.; COWIE, A. Effects of biochar from slow pyrolysis of papermill waste on agronomic performance and soil fertility. Plant and Soil, v.327, p.235-246, 2010. DOI: 10.1007/ s11104-009-0050-x.

WOOLF, D.; AMONETTE, J.E.; STREET-PERROTT, F.A.; LEHMANN, J.; JOSEPH, S. Sustainable biochar to mitigate global climate change. Nature Communications, v.1, article 56, p.1-9, 2010. DOI: $10.1038 /$ ncomms 1053 .

YANG, L.; LIAO, F.; HUANG, M.; YANG, L.; LI, Y. Biochar improves sugarcane seedling root and soil properties under a pot experiment. Sugar Tech, v.17, p.36-40, 2015. DOI: 10.1007/s12355014-0335-0.

YASODHA, R.; SUMATHI, R.; GURUMURTHI, K. Micropropagation for quality propagule production in plantation forestry. Indian Journal of Biotechnology, v.3, p.159-170, 2004.

ZANETTI, M.; CAZETTA, J.O.; MATTOS JÚNIOR, D. de; CARVALHO, S.A. de. Uso de subprodutos de carvão vegetal na formação do porta-enxerto limoeiro 'Cravo' em ambiente protegido. Revista Brasileira de Fruticultura, v.25, p.508-512, 2003. DOI: 10.1590/S0100-29452003000300037.

ZHOU, Z.; LIANG, K.; XU, D.; ZHANG, Y.; HUANG, G.; MA, H. Effects of calcium, boron and nitrogen fertilization on the growth of teak (Tectona grandis) seedlings and chemical property of acidic soil substrate. New Forests, v.43, p.231-243, 2012. DOI: 10.1007/s11056011-9276-6.

$\overline{\text { Received on August 28, } 2015 \text { and accepted on March 16, } 2016}$ 